\title{
The Colonization and Decolonization of Time
}

\author{
Michael Hauser \\ Institute of Philosophy of the Czech Academy of Sciences
}

\begin{abstract}
The article addresses the issue of leisure in the sense of ancient "schole." It strives to uncover the relationship between Aristotelian concept of theoretical activity and "schole" as vacuity. It shows a paradoxical character of "schole" as purposeless time that forms condition for a meaningful activity. How, then, to restore "schole" as vacuity today, when colonization of time expands?
\end{abstract}

Keywords: time, leisure, “schole,” Platon, Aristotle, Marcuse, neoliberalism

We can ask whether nowadays leisure in the sense of ancient "schole" exists. Is there time that is actually free of everyday worries and divested of time patterns bound to the working process? According to Adorno, free time is being colonized by entertainment but entertainment and labor are becoming more and more similar in their structure even though they are separated by lines of demarcation. "Pleasure and Spirit (Geist) are being driven out of both in equal measure. In one as the other, brute seriousness and pseudo-activity prevails" (Adorno 2006). ${ }^{1}$ A radical response to the colonization of leisure time was given by Guy Debord and Situationists, who coined the motto "Never work!” (Debord 1994). ${ }^{2}$ They developed a strategy of resistance based on adopting an extreme position. The resistance by way of an extreme can be spoken of. An extreme position expands in society: "Work still!" Your free time is measured by the job performance. Free time is a relaxation, a recovery period, for you to be able to work better. The Situationist strategy consisted in the fact that we consciously take the opposite extreme position that becomes a starting point. The relationship between labor and leisure time is then reversed. The aim is to measure labor by leisure time and to change the perception of time. This operation could be called the decolonization or the detoxification of time in which time shall be freed of its relationship to the working process. The Situationist operation is concerned about the very leisure time and its re-creation.

By adopting this extreme position, Situationists de facto strove to restore the ancient Greek "schole" that is leisure time which is not determined by working time but determines it in a certain sense. As it is known, this time was characterized by not being filled with the gainful occupation and, if possible, with states of the soul caused by existential worries. It was time, to which working time pointed. Aristotle conveyed succinctly the ratio of these two kinds of time: "We are occupied or are without leisure so that we may be at leisure" (2011). ${ }^{3}$ The ancient Greek term "schole" is derived from the verb "echein," which had originally the stem "sech"-witness the aorist (the aorist infinitive: “schein”). In the aorist shape, this verb took on the meaning "to detain someone from something," and in the presence mediopassive "to keep away from something" or "to abandon something." The term "schole" expressed a privative act: the refraing from an activity or the

Michael Hauser, Ph.D., Department of Contemporary Continental Philosophy, Institute of Philosophy of the Czech Academy of Sciences, Czech Republic; main research field: Critical Theory, Post-Marxism. Email: hauser@sok.bz. 
interrupting of an activity. It indicated free time, repose, relaxation. Its antonym "ascholia" is formed by alpha privativum voicing a double negation (Similarly it is the case with the Latin word "negotium" which is the negation of the word "otium"). This grammar reflects way of understanding the relationship between leisure time ("schole”) and working time ("ascholia”) in ancient society.

As common interpretation puts it, Plato and Aristotle conceived "schole" as time destined to be filled with a higher type of activity, especially intellectual activity. It is in conformity with the further development of the concept "schole," which was referred to as "school" in the sense of a philosophical school or an educational institution. Plato in the dialogue Theaetetus, however, introduced the element of randomness. "Schole" enables us to turn away from the given question and wander at will from one subject to another, and from a second to a third, caring not whether our words are many or few. ${ }^{4}$ Leisure does not coincide completely with intellectual activity. It is not a time span which is designed for a pre-given purpose ("telos"), even if the purpose of activity was knowledge. "Schole" in this meaning is not identical with the school. "Schole" exists as a time without "telos" and only this kind of time becomes a condition for intellectual activity in Plato's and Aristotle's sense. It is the kind of time which is not measured: There is no "clepsydra" measuring out the length of speech on trial, as we read in the Plato's dialogue Theaetetus. This sort of time does not contain any quantitative determinations and its most appropriate name could be vacuity. "Schole" is characterized by absenting purpose and quantity. It is vacuous and that is what renders possible something to arise.

The impressive idea then comes up that the purposelessness of time is a condition for theoretical activity. Philosophical activity does not lead to the objectification of time, which would occur if time in question were measured regarding "telos." In other words, philosophical activity ("theoria”) is not assessed by Plato and Aristotle in accordance with a specific goal (for example to solve this or that philosophical problem)—witness Plato's dialogues that almost never end with a solution. At the end, there is no clear conclusion. Plato's dialogues are based on "schole" free from all the metrics that would have evaluated their results. It is similar to Aristotelian conception of the most valuable "desirable activity." It is an activity in which there is no set goal saving the activity itself. It's not an arbitrary action, but only the one which is associated with virtue ("arête") and seriousness. ${ }^{5}$ It would seem that these requirements introduce the criterion of purpose in leisure ("schole”). Aristotle, however, understood this differently. In his reflections on happiness (“eudaimonia”), he asked what brought the most lasting and purest pleasure. By way of exclusion method, he then came to the fact that it was only a certain type of activity, which was theoretical activity. It was because that "the most excellent of the things in us is the intellect and the things with which the intellect is concerned are the most excellent of the things that can be known" (2011). ${ }^{6}$ This activity, however, is not assessed in accordance with other standards, and even not with a quantity of researched things or with an amount of other performances. It is the activity that as such presents "telos," because the highest degree of happiness is found in it.

Aristotle said that happiness resided in leisure ("schole"). This statement suggests that a prerequisite for theoretical activity remains "schole" in the sense of time without a predetermined purpose. This time cannot turn into time designed for something, even though it is time predetermined for a theoretical activity. If so, "schole" would be deprived of its negative character given by the fact that it is time freed of all duties. "Schole" as time without purpose is needed to keep precisely so that happiness should not appear as duty. If "schole" transformed into a time span, the purpose of which is happiness created by a theoretical activity, the very nature of happiness would change. This happiness would begin to act as a measure against which we would assess our leisure. The measure of happiness would provoke anxiety. We have still to ask ourselves whether our happiness 
is sufficient with respect to the ideal of happiness characterized by lasting and pure pleasure. Happiness would cease to be valuable in itself. "Schole" without all constraints is therefore a condition for leisure to be able to be fulfilled with the "self-sufficient" activity yielding happiness. As soon as "schole" was subjected to happiness measuring its meaningfulness, happiness would become unattainable.

The purposelessness of "schole" is a prerequisite for the purposefulness of a theoretical activity, namely the purposefulness residing in happiness. "Schole" is vacuity divested of all determinations (a purpose, duties, existential worries), and vacuity forms a necessary condition for arising a content, which has a purpose in itself. It is one of the most mysterious things of European philosophy. Vacuity appears to be a necessity. Without introducing vacuity, content cannot be taking form as a self-sufficient content. In other words, a self-sufficient content needs vacuity as its substratum to interrupt the flow of experiences, meanings, and practices which are determined by a purpose. In fact, this flow prevents some content (thought, activity) from relating only to itself. The self-relatedness of content presupposes a continuum filling most of the time of our lives to be interrupted. Introducing vacuity as a gap in a purposive time continuum forms the border between the world of purpose and the world of self-sufficiency.

But there is another question: Suppose the gap ("schole”) does not determine the content of what it will be filled with. It does not specify whether in leisure we are to be active or does not stipulate what to deal with. The question is whether there should be a kind of a meaningful activity (thinking, game, sports etc.) to keep schole. We can ask if "schole" itself is exposed to the measure of purpose. May complete idleness lead to a loss of its meaning and its possible cancellation?

"Schole" as idleness is sometimes used as an argument against extending leisure. What would people do with an extended leisure? People are said to be bored watching TV or lying on the sofa, so it is better for them to go to work. This argument actually states that "schole" filled with idleness is not meaningful, and therefore can be reduced or may be even cancelled. "Schole" is approved on condition that people can handle it properly. Neoliberal ideology produces this argument for the sake of the Labor Code reform which allows to extend the working time. It acts as a severe arbiter of leisure. On the other hand, neoliberalism alleges that people are reasonable enough to decide themselves about their preferences (the argument against economical state intervention).

According to neoliberal ideology, at the same time the man is responsible and irresponsible. He or she is responsible when making a choice, for example signing an employment contract or buying goods. He or she is free and bears responsibility for their decisions. In the post-communist version of neoliberalism, which may be understood as neoliberalism in the purer shape than in Western countries, there is no one to be blamed for poor quality goods or inhuman working conditions. As Václav Klaus put it, you were not forced to buy these goods: You made your choice. But as you decided, you had to accept all the consequences.

This ideology implies that ignorance is no excuse. Once someone decides to do something, then any unforeseen situation resulting from the decision should be charged to his or her account. Neoliberal ideology holds the concept of man as a being who is guilty about not being omniscient. Man is also responsible for the decision, the consequences of which are catastrophic for him or her, and this decision would not be made, if these consequences were knowable for him or her.

As for the issue of leisure, however, neoliberal ideology divulges a degrading concept of man: As we are not forced to do something, sooner or later we fall into idleness. It is just the issue of leisure that shows best that neoliberalism takes coercion for an essential means to activate people. 
Neoliberalism assumes that man left to himself or herself, i.e., someone being without external coercion and therefore free in accordance with the neoliberal definition of freedom, becomes passive and falls into idleness. Free man is here actually contradiction. As for leisure, neoliberalism concludes that a person needs external interventions (an economic coercion) to behave reasonably. As a coercion lacks and leisure in the sense of "schole" occurs, people cease to behave reasonably and fall into idleness. Leisure in the neoliberal account is extremely purposive: It is an instrumental "schole.” Leisure is measured by the working time and the content of leisure is compared with the content of the working time. There may be a fear of time, which is not subject to an economic coercion. People can actually escape "freedom" conferred on them by neoliberalism, which is freedom harboring coercion.

"Schole" is ultimately a paradoxical notion. If we conceive it as a time span destined to some kind of activity, then "schole" is not actually vacuity but represents only another sort of "ascholia" because its purpose lies outside it in the sphere of activity. In this concept, "schole" has not end in itself, but is bound to its content. "Schole" without meaningful activity would then become meaningless. If we, however, envisage "schole" as having end in itself, i.e., we stand up for its vacuity, we do not know how this vacuity to justify without appealing to any possible effect of this vacuity, e.g., leisure as a condition for some kind of activity which otherwise cannot be put forward. "Schole" in the sense of a self-sufficient vacuity is unjustifiable. But as said above, "schole" as a self-sufficient vacuity is a condition for some activities such as Aristotelian intellectual one.

This paradox may be answered in two ways. "Schole" in the sense of a self-sufficient vacuity can be justified retroactively. As far as we want to keep that specific type of activities, it is necessary to postulate a self-sufficient vacuity that renders them possible. Today, when time has been colonized by external purposes, we should first learn leisure as vacuity, i.e., restore the ability of "idleness" about which we read in a fairy tale for adults "Momo, or, the Curious Story about the Time Thieves and the Child Who Returned the People's Stolen Time” by Michael Ende. ${ }^{7}$ The loss of leisure is here portrayed as the inability to interrupt everyday worries and enjoy the things around us a few moments a day. This results in the fact that people become unable to listen to each other. Leisure thus represents a condition for a meaningful communication.

The second answer to the paradox of "schole" may be more profound. It consists in disappearing a very call for a justification of the vacuity. This call arises from the fact that society is ruled by the performance principle and there is compulsion to measure everything against this principle, as Herbert Marcuse put it. ${ }^{8}$ According to him the alternative society is, however, possible which would replace the performance principle by the pleasure one. This society would be freed to being able to affirm being human as end in itself. "Schole" as vacuity would not be necessary to justify any longer because the call for its justification stemmed from the performance principle. It can be assumed that in such a society "schole" would never be completely vacuous as being filled with pleasure. The self-sufficiency of "schole" would take on a meaning that does not come from what is external to it. It would be a pleasure from time itself.

\section{Notes}

1. Adorno, Th.W., Minima Moralia: Reflexions on Damaged Life. London-New York, Verso, 2006, 130 (par. 84). Another author speaking on the colonization of time is Lukács who accounts for the transformation of qualitative time perception into quantitative one. Time changes into a quantum of units expressing a performance standard. According to Lukács, time is assimilated to space. Lukács, G., Geschichte und Klassenbewußtsein. Berlin, Luchterhand, 1968, 264. 
2. Guy Debord wrote about the violent expropriation of time, which was a condition for people to become "free" producers and consumers. Time turns into "consumable pseudo-cyclical time.” Debord, G., The Society of the Spectacle. New York, Zone Books, 1994, s.112 (par. 153).

3. Aristotel's Nicomachean Ethics. Trans. Robert C. Bartlett and Susan D. Collins. Chicago, The University of Chicago Press, 2011, 224 (1177b5). Aristotle presents actions here which are not compatible with leisure (the political and warlike ones). In Theaetetus, Plato mentioned another action of this kind which is advocacy: "The lawyer is always in a hurry; there is the water of the clepsydra driving him on, and not allowing him to expatiate at will.” Plato: Theaetetus. Trans. Joe Sachs. Newburyport, Focus Publishing, 2004 (172d).

4. Cf. Plato: Theaetetus. Trans. Joe Sachs. Newburyport, Focus Publishing, 2004 (172d).

5. Aristotel's Nicomachean Ethics. Trans. Robert C. Bartlett and Susan D. Collins. Chicago, The University of Chicago Press, 2011, 223 (1177a4).

6. Ibid., 224 (1177a22).

7. Ende, Michael, Momo. London, Puffin Books, 1985.

8. Marcuse, H., Eros and Civilization. London, Sphere Book, 1969.

\section{Works Cited}

Adorno, Th.W. Minima Moralia: Reflexions on Damaged Life. London-New York: Verso, 2006.

Debord, G. The Society of the Spectacle. New York: Zone Books, 1994.

Ende, Michael. Momo. London: Puffin Books, 1985.

Lukács, G. Geschichte und Klassenbewußtsein. Berlin: Luchterhand, 1968.

Marcuse, H. Eros and Civilization. London: Sphere Book, 1969.

Plato. Theaetetus. Trans. Joe Sachs. Newburyport: Focus Publishing, 2004.

Robert, C. Bartlett and Susan D. Collins. Aristotel's Nicomachean Ethics. Chicago: The University of Chicago Press, 2011. 